\title{
EFFECTS OF CAPSAICIN SUPPLEMENTATION ON PRODUCTIVE AND PHYSIOLOGICAL PERFORMANCE OF PEKIN DUCKS DURING SUMMER SEASON
}

\author{
W.A.H. Ali. ${ }^{1}$; A.M.H. Ahmed ${ }^{2}$ and Hoda E. El-Gabry ${ }^{3}$ \\ ${ }^{1}$ Rabbit, Turkey and Water Fowl Breeding Research Department, Animal Production Research \\ Institute, Egypt. \\ ${ }^{2}$ Poult. Prod. Dep., Fac of Agric., Ain Shams University, Egypt. \\ ${ }^{3}$ Poultry Nutrition Department, Animal Production Research Institute. Egypt.
}

(Received 18/1 / 2016, Accepted $26 / 12$ /2016)

\section{SUMMARY}

\begin{abstract}
$\mathrm{T}$ he aim of this study was to evaluate the effect of using graded levels of capsaicin on growth performance, nutrients digestibility coefficients, serum metabolites, oxidative responses and intestinal digestive enzymes activity of Pekin ducks. One hundred and twenty $14 \mathrm{~d}$ old Pekin ducks were randomly divided into four groups of 30 ducks. The first group was fed on the basal diet (control), while groups 2, 3 and 4 were given the basal diet supplemented with 50, 100 and $150 \mathrm{ppm}$ capsaicin, respectively. The results showed significant improvement in body weight and feed conversion of ducks, particularly with the high level $(150 \mathrm{ppm})$ followed by those of the mid one (100pm). Moreover, supplemental capsaicin with different levels enhanced digestibility coefficient values especially with ether extract (EE) and nitrogen free extract (NFE) in Pekin ducks. The serum level of total proteins, globulin, high density lipoprotein (HDL), triiodothyronine (T3), thyroxin (T4) and antioxidant enzymes was significantly increased for ducks fed on diets contained either 100 or $150 \mathrm{ppm}$ capsaicin. But, the concentrations of total lipid, cholesterol, triglycerides, low density lipoprotein (LDL), glucose and malondialdehyde (MDA), which is the primary stable by-product of lipid peroxidation, were reduced. On the other hand, the albumin level didn't significantly affected by dietary capsaicin supplementation. A significant increase in the activities of amylase, lipase and trypsin enzymes was found throughout the small intestine portions with supplemental capsaicin. It is concluded that, capsaicin supplementation with $100 \mathrm{ppm}$ up to $150 \mathrm{ppm}$ was sufficient to enhance the growth performance traits, nutrients digestibility, thyroid and antioxidant system in growing Pekin ducks. In addition to, using these natural feed additives had clear favorable effect on enzymatic and microbiological profile in small intestine, without adverse effects on liver activity.
\end{abstract}

Keywords: Capsaicin, Pekin ducks, growth, serum constituents, antioxidant enzymes, digestive Enzyme

\section{INTRODUCTION}

High temperature imposes severe stress on birds and leads to important economic losses in the poultry industry. Although birds perform well within a relatively wide range of temperatures, between 10 and $27^{\circ} \mathrm{C}$ (Daghir, 2009), temperatures above $30^{\circ} \mathrm{C}$ may cause stress in adult hens (Daghir, 1995) and broiler chickens (Geraert et al., 1996). Several feed compounds are related to stress levels in animals and some may be used for preventing heat effect. Between them are some antioxidants like capsaicin (Lee et al., 2003), because the oxidative injury induced by high ambient temperatures has been demonstrated in several studies ( Mujahid et al., 2006), and the oxidative stress should be considered as part of the stress response of chickens to heat exposure.

Hot red pepper is one of the most important herbs, which is widely used in human feed all over the world; Capsinoids are widely present at low levels in chilli pepper fruit, it includes capsaicin, dihydrocapsaicin and it has a very favorable safety profile (Vicente et al. 2007). Capsaicin, a homovanillic acid derivative (8-methyl-N-vanillyl-6-moneamide) is an irritant and vasoactive compound from chilli (Capsicum annum) powder (Vicente et al. 2007). Dried pods of Capsicum annum or chilli contain 1.8\% capsaicin (Pruthi 2003).

Capsaicin has been reported to have effects as alkaloid component can induce body heat as well as increase energy expenditure, anti-inflammatory (Choi et al., 2011) and antioxidant properties (Henning et 
al., 2011). It also decrease in adipose tissue mass has a role to play in weight management. In addition, capsaicin affects various physiological functions which include intestinal peristalsis (Hellgren et al., 2000), gastroprotection (Szoscanyi and Bartho, 2001), temperature regulation (Nomoto et al., 2004), modulation of the energy metabolism (Kawada et al., 1986), immune status (Yu et al., 1998) and blood neuthrophils (Zhukova and Makarova, 2002). Capsaicin has also been found to exert protective effect against Salmonela enteritidis infection in laying hens (Vicente et al., 2007). The presence of the capsaicin in these species has long been associated with strong analgesic properties (Cordell et al., 1993), alterations in the $\mathrm{pH}$ of gastrointestinal tract epithelial cells, prevention of microbial infection (Tellez et al., 1993).

The main purpose of this study was carried out to evaluate the effect of different dietary levels of capsaicin on the performance and oxidative status of ducks.

\section{MATERIALS AND METHODS}

The experimental study was carried out at Poultry Experimental Unit, Agricultural Experiment and Research Station at Shalakan, Faculty of Agriculture, Ain Shams University, Egypt.

\section{Birds, Diet and Experimental Design}

One hundred and twenty, 14-day old of unsexed Pekin ducks were used from June to July in 2016 and were weighed and equally distributed among four groups, each group contained three replicates; each replicate consisted of 10 birds. The first group was fed on the basal diet (control), while groups 2, 3 and 4 were given the basal diet supplemented with 50,100 and $150 \mathrm{ppm}$ capsaicin, respectively. Capsaicin purchased from SIGMA-ALDRICH Chemical Co., India was mixed in the powdered basal diet at a concentration of 50, 100 and 150 p.p.m. (w/w). These experimental diets were prepared on a weekly basis and stored in a cold room $\left(<4^{\circ} \mathrm{C}\right)$ until use. During the experimental period (14-56 day of age), the birds were reared on floor in open-sided house and were kept under the same managerial, hygienic and environmental conditions till the age of 56 day. Feed and water were provided for ad libitum consumption throughout the experimental period. Birds were maintained on a light cycle of 16L: 8D. The grower diet (Table 1) was formulated to meet all requirements recommended by NRC (1994).

Table (1). Composition and calculated analysis of basal diet.

\begin{tabular}{|c|c|}
\hline Ingredient $\%$ & Grower (14-56) \\
\hline Yellow corn & 58.50 \\
\hline Soybean meal (44\%) & 35.50 \\
\hline Corn gluten meal (60\%) & 2.00 \\
\hline Di-calcium phosphate & 1.90 \\
\hline Lime stone & 1.20 \\
\hline Sodium chloride & 0.30 \\
\hline Vit. and min. premix $*$ & 0.30 \\
\hline DL- methionine & 0.20 \\
\hline L- lysine $\mathrm{HCl}$ & 0.10 \\
\hline Total & 100 \\
\hline Crude protein $(\mathrm{CP})$ & 21.75 \\
\hline Crude fibber (CF) & 3.74 \\
\hline Ether extract (EE) & 1.90 \\
\hline $\mathrm{ASH}$ & 6.17 \\
\hline \multicolumn{2}{|l|}{ Calculated values: } \\
\hline Metabolizable energy (Kcal/kg) & 2825.80 \\
\hline Crude protein $(\mathrm{CP})$ & 22.04 \\
\hline Calcium \% & 1.05 \\
\hline Available phosphorus $\%$ & 0.74 \\
\hline Lysine \% & 1.39 \\
\hline Methionine + Cysteine $\%$ & 0.94 \\
\hline
\end{tabular}


The body weight gains of birds were measured individually and feed consumption and feed conversion efficiency (g feed: g gain) were measured weekly.

At the end of the experimental period three birds from each group were housed in separate metabolic cages for 5 days. After a 3 days preliminary period, feed intake and excreta were measured and collected during 5 days. The proximate analyses of feed and dried excreta were determined according to AOAC (1995).

Nine blood samples per group (three/ replicate) were obtained from left wing vein at 56 day of birds' age for measurement of blood parameters. Five ml blood was taken from each bird in a sterile plastic syringe. The blood samples were collected in clean centrifuge tubes and left at room temperature for 20 minutes to clot. They were centrifuged at $3000 \mathrm{rpm}$ for $15 \mathrm{~min}$ for separation of blood serum.

Quantitative determination of blood serum was included the following: total proteins, albumin, globulins (determined by subtraction the value of albumin for the sample from its corresponding value for total proteins), glucose, total lipids, total cholesterol, Low Density Lipoprotein (LDL-cholesterol), High Density Lipoprotein (HDL cholesterol) and liver enzymatic activity (AST and ALT) concentrations by using Atomic Absorption spectrophotometer and suitable commercial diagnostic kits following the same steps as described by manufactures (Bio-Diagnostics company, Egypt). Concentration of triiodothyronine (T3) and thyroxin (T4) were determined using commercial enzyme immunoassay test kit purchased from Taytec Incorporation (7278 Aldercrest Dr., Mississauga, ON, L5N 7N8, Canada). Serum Insulin hormones using kits supplied by Daimmond Diagnostic (Giza, Egypt). Serum Malondialdehyde (MDA) was measured by the method described by Ohkawa et al. (1979). Superoxide dismutase (SOD) and catalase (CAT) were measured in erythrocytes calorimetrically according to methods of Nishikimi et al. (1972) and Aebi, (1984), respectively.

Intestine was removed and the digest contents of this intestinal segment $(1 \mathrm{~g})$ were collected and homogenized with $10 \mathrm{ml}$ phosphate buffer solution. The digest specimens were sent packed on ice to the laboratory (Microbiological Laboratory, MERCIN, Faculty of Agriculture, Ain Shams University) for enumeration of total bacteria, E. coli and Lactobacilli spp. The contents of duodenum, jejunum and ileum were collected, form the slaughtered bird, weighed and kept in equal volumes of sterilized physiological saline. They were then individually centrifuged and the supernatant fluids were decanted and used for determination of some digestive enzymes activity (amylase, lipase and trypsin) as described by Nitsan et al. (1991).

Data were statistically analyzed according to SAS (2001) computer program using the following fixed model: $\mathrm{Y}_{\mathrm{ij}}=\mu+\mathrm{T}_{\mathrm{i}}+\mathrm{e}_{\mathrm{ij}}$

Where: $Y_{i j}=$ the observation; $\mu=$ overall mean; $T_{i}=$ effect of treatments; $\mathrm{eij}=$ random error component assumed to be normally distributed. Duncan's multiple range tests was performed (Duncan, 1955) to detect significant differences among means.

\section{RESULTS AND DISCUSSION}

\section{Productive performance}

The effects of dietary capsaicin supplementation at different levels on LBW, BWG and FCR of Pekin ducks are listed in Table 2. Results showed significant improvement in all studied productive performance data as the level of dietary capsaicin level increased. However, the group of $100 \mathrm{ppm}$ capsaicin didn't significantly differ from those of $50 \mathrm{ppm}$.

The effect of feeding graded level of capsaicin indicated that supplemented birds with capsaicin had no significant effect on feed consumption in all levels (Table, 3). The absence of significantly affects of this additive on feed intake may probably due to the birds requires of long time to adapted to this additive. Body weight gain and feed conversion ratio in the present study, showed a significant improvement of birds that fed on the diets supplemented with capsaicin at various levels compared with that control group. Our results were compatible also with, El Tazi (2014) who reported that inclusion of capsaicin in the diet at levels of $0.5,0.75$ and $1 \%$ improvement significantly body weight gain and feed conversion ratio of broiler chicks. The better body weight gain and feed conversion ratio may be due to the antimicrobial properties of capsaicin the activity ingredients in this supplement which possess which can lead to decrease the harmful microbes in digestive system and increased the mucosa and sub-mucosa thickness of small intestine and absorption surface of duodenum an alliums of broiler (Chiej, 1984). 
Meanwhile, it might be to the active compound (capsaicin) that improves feed conversion which is reflected on body weight improvement (Al- Kassie et al. 2012) Also, these results were agreement with (El Husseiny et al., 2002) who stated that the levels of 1, 1.5 and $2 \%$ of bird of the diets improved significantly body weight gain and feed conversion ratio On the other hand, El Husseiny et al., (2002) reported that feed intake of broiler decreased as the level of hot red pepper increased to $2 \%$. However, the results of the present study showed that, capsaicin at different levels of inclusion, performed similar to antibiotic growth promoter on body weight gain, feed intake and feed conversion ratio of Pekin ducks.

Table (2). Productive performance of Pekin ducks fed supplemental capsaicin.

\begin{tabular}{|c|c|c|c|c|}
\hline \multirow{2}{*}{ Item } & \multicolumn{4}{|c|}{ Capsaicin levels (ppm) } \\
\hline & 0 & 50 & 100 & 150 \\
\hline \multicolumn{5}{|c|}{ Live Body weight } \\
\hline $2 \mathrm{wk}$ & $656 \pm 11.95$ & $652.12 \pm 9.28$ & $651.15 \pm 15.37$ & $650.50 \pm 13.58$ \\
\hline $4 \mathrm{wk}$ & $1250.53^{\mathrm{d}} \pm 9.08$ & $1286.36^{\mathrm{c}} \pm 13.62$ & $1353.92^{\mathrm{b}} \pm 5.13$ & $1393.93^{\mathrm{a}} \pm 8.68$ \\
\hline $6 \mathrm{wk}$ & $1623.50^{c} \pm 14.71$ & $1731.67^{\mathrm{b}} \pm 13.30$ & $1755.00^{\mathrm{b}} \pm 15.55$ & $1905.00^{\mathrm{a}} \pm 17.34$ \\
\hline $8 \mathrm{wk}$ & $2091.67^{\mathrm{d}} \pm 23.73$ & $2227.42^{c} \pm 15.81$ & $2297.05^{\mathrm{b}} \pm 17.34$ & $2370.46^{\mathrm{a}} \pm 23.45$ \\
\hline \multicolumn{5}{|c|}{ Body weigh gain } \\
\hline $2-4 \mathrm{wk}$ & $594.53^{\mathrm{b}} \pm 17.04$ & $634.24^{\mathrm{b}} \pm 15.64$ & $702.77^{\mathrm{a}} \pm 15.66$ & $743.43^{\mathrm{a}} \pm 17.73$ \\
\hline $4-6 \mathrm{wk}$ & $372.97^{\mathrm{c}} \pm 16.86$ & $445.31^{\mathrm{b}} \pm 17.91$ & $401.08^{\mathrm{bc}} \pm 16.33$ & $511.07^{\mathrm{a}} \pm 17.46$ \\
\hline $6-8 \mathrm{wk}$ & $468.17^{\mathrm{b}} \pm 23.95$ & $495.75^{\mathrm{b}} \pm 22.01$ & $542.05^{\mathrm{a}} \pm 22.56$ & $465.46^{\mathrm{b}} \pm 20.88$ \\
\hline $2-8 \mathrm{wk}$ & $1435.67^{\mathrm{c}} \pm 29.55$ & $1575.30^{\mathrm{b}} \pm 20.59$ & $1645.90^{\mathrm{ab}} \pm 28.64$ & $1719.96^{\mathrm{a}} \pm 26.66$ \\
\hline
\end{tabular}

Table (3). Feed intake and feed conversion ratio of Pekin ducks fed supplemental capsaicin.

\begin{tabular}{lcccc}
\hline \multirow{2}{*}{ Item } & \multicolumn{4}{c}{ Capsaicin levels (ppm) } \\
\cline { 2 - 5 } Feed intake & 0 & 50 & 100 & 150 \\
$2 \mathrm{wk}$ & $1248.20 \pm 9.20$ & $1247.20 \pm 8.49$ & $1225.42 \pm 9.18$ & $1218.78 \pm 8.83$ \\
$4 \mathrm{wk}$ & $1895 \pm 19.71$ & $1885 \pm 22.10$ & $1854.17 \pm 15.64$ & $1850 \pm 26.82$ \\
$6 \mathrm{wk}$ & $3805.83 \pm 29.06$ & $3888.28 \pm 33.24$ & $3954.17 \pm 26.64$ & $4035.83 \pm 26.82$ \\
$8 \mathrm{wk}$ & $6949.03 \pm 29.86$ & $6992.12 \pm 25.20$ & $7029.58 \pm 29.13$ & $7048.63 \pm 22.50$ \\
Feed conversion ratio & & & \\
$2 \mathrm{wk}$ & $2.12 \mathrm{a} \pm 0.08$ & $1.93 \mathrm{~b} \pm 0.04$ & $1.75 \mathrm{c} \pm 0.04$ & $1.69 \mathrm{c} \pm 0.05$ \\
$4 \mathrm{wk}$ & $5.22 \mathrm{a} \pm 0.30$ & $4.31 \mathrm{bc} \pm 0.20$ & $4.80 \mathrm{ab} \pm 0.28$ & $3.68 \mathrm{c} \pm 0.18$ \\
$6 \mathrm{wk}$ & $8.36 \mathrm{ab} \pm 0.42$ & $8.03 \mathrm{ab} \pm 0.39$ & $7.44 \mathrm{~b} \pm 0.32$ & $8.87 \mathrm{a} \pm 0.42$ \\
$8 \mathrm{wk}$ & $4.86 \mathrm{a} \pm 0.10$ & $4.44 \mathrm{~b} \pm 0.06$ & $4.28 \mathrm{bc} \pm 0.08$ & $4.10 \mathrm{c} \pm 0.06$ \\
\hline$a, b$ and $c:$ Means within a row with different superscripts are significantly different at $(P \leq 0.05)$.
\end{tabular}

\section{Nutrient digestibility}

The effect of treatments on the nutrients digestibility coefficients of dry matter (DM), crude protein $(\mathrm{CP})$, crude fiber (CF), ether extract (EE) and nitrogen free extract (NFE) are summarized in Table 4. Nutrient digestibility coefficients of DM, EE and NFE were significantly $(\mathrm{P}<0.05)$ increased by capsaicin supplementation. Several studies (Garcia et al. 2007) have shown that plant extracts such as capsaicin improved the digestibility values of diets in broilers. They attributed that to the addition of capsaicin to the diet may affected energy metabolism by activating the sympathetic nervous system in animals. However the mechanisms of improvement of digestibility coefficient values of EE by capsaicin may be through increasing the secreation of lipase and secondary bile acids (Platel and Srinivasan, 2004). On the other hand, the improvement of digestibility coefficient values of EE and NFE may be attributed to the potential beneficial effect of these additives capsaicin on gastrointestinal tract micro-organisms and metabolites which be reflected on improving the digestibility of feed nutrients and conversions.

However, no effect of supplementation was detected for CP and CF digestibility (Table 4). Phenolic compounds (capsaicin) of plant extracts did not affect the apparent CP digestibility of diets, whereas, polyphenol compounds known to combine with proteins and consequently block the lysine, tryptophan, and cysteine residues. Protein bound in this form decreased the digestibility and biological value of protein (Rawel et al., 2002). 
Egyptian J. Nutrition and Feeds (2016)

Table (4). Nutrients digestibility coefficients and intestinal bacterial count of Pekin ducks fed supplemental capsaicin.

\begin{tabular}{lcccc}
\hline \multirow{2}{*}{ Item } & \multicolumn{4}{c}{ Capsaicin levels (ppm) } \\
\cline { 2 - 5 } & 0 & 50 & 100 & 150 \\
\hline DM\% & $76.18^{\mathrm{b}} \pm 0.07$ & $76.22^{\mathrm{b}} \pm 0.11$ & $78.12^{\mathrm{ab}} \pm 0.32$ & $79.64^{\mathrm{a}} \pm 0.30$ \\
$\mathrm{CP} \%$ & $72.74 \pm 3.25$ & $72.88 \pm 2.32$ & $72.01 \pm 3.04$ & $72.97 \pm 3.69$ \\
$\mathrm{CF} \%$ & $18.44 \pm 1.18$ & $18.15 \pm 1.23$ & $18.63 \pm 1.96$ & $18.14 \pm 1.35$ \\
EE\% & $75.85^{\mathrm{b}} \pm 0.22$ & $76.11^{\mathrm{b}} \pm 0.22$ & $78.34^{\mathrm{a}} \pm 0.29$ & $79.25^{\mathrm{a}} \pm 0.28$ \\
NFE\% & $75.50^{\mathrm{c}} \pm 0.26$ & $76.56^{\mathrm{bc}} \pm 0.24$ & $78.16^{\mathrm{ab}} \pm 0.32$ & $79.15^{\mathrm{a}} \pm 0.26$ \\
T. count ( log CFU/ g) & $6.44^{\mathrm{a}} \pm 0.11$ & $6.13^{\mathrm{ab}} \pm 0.07$ & $5.85^{\mathrm{b}} \pm 0.18$ & $5.91^{\mathrm{b}} \pm 0.12$ \\
Coliform count ( log CFU/g) & $6.26^{\mathrm{a}} \pm 0.04$ & $6.23^{\mathrm{ab}} \pm 0.09$ & $6.20^{\mathrm{ab}} \pm 0.12$ & $5.95^{\mathrm{b}} \pm 0.11$ \\
Lactic acid count ( log CFU/g) & $3.06^{\mathrm{b}} \pm 0.03$ & $2.92^{\mathrm{b}} \pm 0.13$ & $3.09^{\mathrm{b}} \pm 0.08$ & $3.72^{\mathrm{a}} \pm 0.22$ \\
\hline
\end{tabular}

$a, b$ and $c$ : Means within a row with different superscripts are significantly different at $(p \leq 0.05)$.

\section{Microbial determination}

Data presented in Table 4, show the effect of different dietary treatments on total viable bacteria, coliform and lactic acid bactreia counts in small intestine (mean log $10 \mathrm{CFU} / \mathrm{g}$ ). Lowest value of mean $\log$ CFU/ g of total bacteria were recorded for Pekin ducks fed capsaicin compared to those fed the control diet especially with the mid and high dosages. In addition, lowest value of mean $\log \mathrm{CFU} / \mathrm{g}$ of coliform bacteria were recorded for ducks fed highest capsaicin level (150ppm) compared to those fed other diets. Moreover, feeding (highest capsaicin level $(150 \mathrm{ppm})$ ) diet showed positive effect on lactic acid bacteria counts. These results are in agreement with those obtained by Jamroz et al. (2003) determined that plant extract (carvacrol, cinnamaldehyde and capsaicin) reduced the total E. coli and can control Clostridium perfringens colonization in the intestine and feces of broiler chickens. Antibacterial, anticoccidial, antifungal and antioxidant effects of capsaicin (Chevallier 1996), and which has effects on the resistance to Salmonella enteritidis infection by altering $\mathrm{pH}$ and histological changes (McElroy et al., 1994). In this respect, red pepper leads to increase of acid secretion (Ononiwu et al., 2002). Increased gastric mucus production has been suggested as one mechanism by which capsaicin and chilli exert their gastroprotective effect, and reduction in mucosal mucus depletion which has been found to act as secondary protective effect of capsaicin and chillis (Holzer and Sametz, 1986).

In general, the development of the gastrointestinal tract, especially that of the intestinal mucosa, is related to the stimulation of the process of cell mitosis and the modulation of the enteric microbial flora, where the addition of capsaicin reduces the microbial population, diminishing the competition for nutrients between the bacteria and the host, along with the reduction of direct injuries to the intestinal mucosa (Barreto et al., 2008).

Another explanation, it has been reported that, the antibacterial activity of capsaicin was suggested to be associated with the presence of phenolic constituents (Shan et al., 2007), even though the exact antimicrobial mechanism of phenolic compounds is not clear. The ability of phenolic compounds to alter microbial cell permeability, thereby permitting the loss of macromolecules from the cell interior, could help explain some of the antimicrobial activity Bajpai et al., 2008), or it might be that phenolic compounds interfere with membrane function and interact with membrane proteins, causing deformation in structure and functionality (Bajpai et al., 2008).

\section{Digestive Enzyme Activities}

Effect of feeding pekin ducks on diets contained various capsaicin dosages on the digestive enzyme activities in different segments of small intestine (duodenum, jejunum and ileum) are presented in Table (5). It is clearly observable that, the activity of amylase enzyme in the duodenum was significantly lower in the control group than the groups of capsaicin. Similar trend was achieved in the jejunum portion, although the absence of significant differences between the control chicks and those of 50ppm capsaicin. The activity values within the ileum were only significant for pekin ducks received the highest capsaicin level (150ppm). Concerning lipase enzyme the current findings indicated that, its activity was affected with the addition of capsaicin. Where, the statistical significant differences were noted only between the group control group and the highest capsaicin level (150ppm) in both the jejunum and ileum. This may be associated with the action of capsaicin in oxidation of fatty acids as previously mentioned herein. Results of trypsin enzyme activity showed that, it was elevated significantly with supplemental capsaicin with 
150ppm compared with the control treatment within the first small intestinal portion (duodenum). Similar trend, however, non significant was obtained in the second and third portions (jejunum and ileum).

The presence of extracts containing capsaicin (red pepper) stimulated production and secretion of salivary amylase and pancreatic and intestinal enzymes in birds (Lee et al. 2004). Platel and Srinivasan (2000), when they affirmed that capsaicin has showed to be efficient in stimulating salivation in pigs (amylase production) and by (Brugalli, 2003), who reported that there is increase in the secretion of pancreatic and intestinal enzymes, promoting, thus, reduction in the intestinal viscosity and improving the digestive process.

In general, the results showed that there was a tendency toward increasing the activity of all tested digestive enzymes (amylase, lipase and trypsin) throughout the small intestine portions with supplemental capsaicin. Thus, the dietary capsaicin, which either enhanced the activity of digestive enzymes or caused a higher secretion of bile acids, also reduced the food transit time at the same level of consumption. This reduction in food transit time could probably be attributed to acceleration in the overall digestive process as a result of increased availability of digestive enzymes and of bile acids that facilitate fat digestion (Platel and Srinivasan, 2004). These results may interpret, to a great extent, the current growth performance data.

Table (5). Digestive enzyme activities (Unit/dl) throughout the small intestine of Pekin ducks fed supplemental capsaicin

\begin{tabular}{|c|c|c|c|c|}
\hline \multirow{2}{*}{ Item } & \multicolumn{4}{|c|}{ Capsaicin levels (ppm) } \\
\hline & 0 & 50 & 100 & 150 \\
\hline \multicolumn{5}{|c|}{ Enzyme type (U/dl) in Duodenum } \\
\hline Amylase & $1.97^{\mathrm{c}} \pm 0.04$ & $1.96^{\mathrm{c}} \pm 0.07$ & $2.28^{\mathrm{b}} \pm 0.11$ & $2.68^{\mathrm{a}} \pm 0.06$ \\
\hline Lipase & $8.97^{\mathrm{c}} \pm 0.19$ & $8.70^{c} \pm 0.19$ & $9.98^{\mathrm{b}} \pm 0.27$ & $10.80^{\mathrm{a}} \pm 0.15$ \\
\hline Trypsin & $24.54^{\mathrm{b}} \pm 0.85$ & $26.73^{\mathrm{ab}} \pm 0.32$ & $27.78^{\mathrm{ab}} \pm 0.68$ & $31.76^{\mathrm{a}} \pm 3.33$ \\
\hline \multicolumn{5}{|c|}{ Enzyme type (U/dl) in Jejunum } \\
\hline Amylase & $2.01^{\mathrm{c}} \pm 0.06$ & $2.08^{\mathrm{bc}} \pm 0.10$ & $2.32^{\mathrm{b}} \pm 0.10$ & $2.64^{\mathrm{a}} \pm 0.07$ \\
\hline Lipase & $8.99^{c} \pm 0.19$ & $8.62^{c} \pm 0.19$ & $9.98^{\mathrm{b}} \pm 0.22$ & $10.69^{\mathrm{a}} \pm 0.20$ \\
\hline Trypsin & $24.43 \pm 0.76$ & $24.17 \pm 0.19$ & $24.90 \pm 1.39$ & $24.43 \pm 1.70$ \\
\hline \multicolumn{5}{|c|}{ Enzyme type $(U / d l)$ in Ileum } \\
\hline Amylase & $2.13^{\mathrm{b}} \pm 0.11$ & $2.01^{\mathrm{b}} \pm 0.13$ & $2.23^{\mathrm{b}} \pm 0.07$ & $2.66^{\mathrm{a}} \pm 0.06$ \\
\hline Lipase & $8.92^{c} \pm 0.16$ & $8.82^{\mathrm{c}} \pm 0.17$ & $9.73^{\mathrm{b}} \pm 0.35$ & $10.58^{\mathrm{a}} \pm 0.17$ \\
\hline Trypsin & $24.43 \pm 0.76$ & $24.95 \pm 1.40$ & $24.12 \pm 1.48$ & $24.87 \pm 1.51$ \\
\hline
\end{tabular}

$a, b$ and $c$ : Means within a row with different superscripts are significantly different at $(p \leq 0.05)$.

\section{Serum Constituents}

Data presented in Table 6, that dietary addition of capsaicin insignificantly increased serum total proteins especially with the mid and high dosages when compared with the unsupplemented control ones.

Results in Table 6 illustrated that; supplemental capsaicin could effectively reduce the serum concentrations of total lipid, cholesterol, triglycerides and LDL. Contrary, the level of serum HDL was raised due to capsaicin addition. Moreover, the effect was markedly observed with the high dosage (150ppm) followed by the mid one (100ppm). These results were agreement with Kang et al., (2007) published that capsaicin suppressed the oxidation of LDL, lowered LDL, and inhibited the transformation of cholesterol to oxidized products. A Capsaicin treatment was found to decrease LDL and TG, and increase HDL with no noticeable affect on serum total cholesterol. The reduction in serum cholesterol in diet supplementing by capsaicin could be attributed to the active capsaicin which inhibit the activity 3hydroxyl-3-methyl glutaryle-co-A reeducate will lower serum cholesterol in poultry up to $2 \%$ (Srinivasan and Sambaiah, 1991), also they reported that capsaicin could stimulate the conversion of cholesterol to bile acids, an important path way of excretion of cholesterol. On the other hand, these results indicate that extensive consumption of capsaicin reduce adiposity, a phenomenon which can be explained partly by the enhancing effects of capsaicin on energy and lipid metabolism via catecholamine secretion from the adrenal medulla (Kawada et al., 1988). Since an increase in sympathetic nervous system (SNS) activity affects food intake behaviour (Raben et al., 1996), they hypothesized that the usage of capsaicin to the diet can decrease food intake and that this is associated with an increase in SNS activity and reflected that on energy and lipid metabolism. 
Egyptian J. Nutrition and Feeds (2016)

Table (6). Serum biochemical constituents and liver functions of Pekin ducks fed supplemental capsaicin

\begin{tabular}{lcccc}
\hline \multirow{2}{*}{ Item } & \multicolumn{4}{c}{ Capsaicin levels $(\mathrm{ppm})$} \\
\cline { 2 - 5 } & 0 & 50 & 100 & 150 \\
\hline Total protein $(\mathrm{g} / \mathrm{dL})$ & $4.96 \pm 0.17$ & $5.08 \pm 0.16$ & $5.34 \pm 0.17$ & $5.45 \pm 0.12$ \\
Total lipid $(\mathrm{mg} / \mathrm{dL})$ & $963.38^{\mathrm{a}} \pm 13.76$ & $904.17^{\mathrm{b}} \pm 12.62$ & $855.59^{\mathrm{c}} \pm 13.01$ & $795.54^{\mathrm{d}} \pm 13.67$ \\
Cholesterol $(\mathrm{mg} / \mathrm{dL})$ & $311.38^{\mathrm{a}} \pm 2.97$ & $249.61^{\mathrm{b}} \pm 2.38$ & $195.59^{\mathrm{c}} \pm 1.58$ & $195.55^{\mathrm{c}} \pm 1.67$ \\
TG $(\mathrm{mg} / \mathrm{dL})$ & $212.06^{\mathrm{a}} \pm 2.76$ & $206.06^{\mathrm{a}^{\mathrm{b}} \pm 3.15}$ & $201.82^{\mathrm{b}} \pm 1.89$ & $201.57^{\mathrm{b}} \pm 1.32$ \\
$\mathrm{HDL}(\mathrm{mg} / \mathrm{dL})$ & $26.13^{\mathrm{b}} \pm 1.27$ & $36.85^{\mathrm{a}} \pm 1.86$ & $35.96^{\mathrm{a}} \pm 1.08$ & $38.70^{\mathrm{a}} \pm 1.69$ \\
LDL $(\mathrm{mg} / \mathrm{dL})$ & $172.74^{\mathrm{a}} \pm 0.25$ & $162.55^{\mathrm{b}} \pm 3.47$ & $154.79^{\mathrm{c}} \pm 1.62$ & $151.19^{\mathrm{c}} \pm 2.68$ \\
AST $(\mathrm{U} / \mathrm{I})$ & $111.86 \pm 1.59$ & $106.42 \pm 2.44$ & $103.50 \pm 1.52$ & $105.61 \pm 2.63$ \\
ALT $(\mathrm{U} / \mathrm{I})$ & $34.31 \pm 2.21$ & $34.40 \pm 2.19$ & $34.58 \pm 2.37$ & $35.60 \pm 1.71$ \\
Glucose $(\mathrm{mg} / \mathrm{dL})$ & $178.70^{\mathrm{a}} \pm 3.01$ & $175.52^{\mathrm{a}} \pm 1.65$ & $157.28^{\mathrm{b}} \pm 1.31$ & $151.55^{\mathrm{c}} \pm 0.46$ \\
\hline a b and $c:$ Means within a row with different superscripts are significantly different at $(p \leq 0.05)$.
\end{tabular}

It was clearly evident from (Table, 6 ) that dietary addition of capsaicin significantly decreased serum glucose, especially with the mid and high dosages. Whereas, ducks whose diet was contained the low capsaicin level had slightly higher serum glucose when compared with the unsupplemented control ones. In a study by Kang et al. (2010) dietary capsaicin decreased glucose levels in the plasma. Capsaicin which is the main component of chilli inhibits the intestinal absorption of glucose and this justifies the hypoglycaemic effect of chilli as pointed by Al- Kassie et al. (2011). However, the lower circulatory glucose concentration in the capsaicin supplemented birds was perhaps indicative of an increased turnover rate and utilization of glucose at the tissue level.

In general, the increase in glucose concentration in control group is directly responsive to an increase in glucocorticoids (Borges et al., 2007), which can result from various stressors including heat stress. Glucocorticoids have primary effects on metabolism, stimulating gluconeogenesis from muscle tissue proteins. Rashidi et al. (2010) reported that high environmental temperature increased levels of plasma glucose and cholesterol and reduced protein level. Comparable results were obtained in this study where concentration of serum glucose and cholesterol increased in heat stressed control. The increase in blood lipids under heat stress was explained by Rashidi et al. (2010) that high temperature reduced feed intake and broilers compensate their need to energy by lipolysis of body lipid that it causes increasing the blood cholesterol and triglycerides. At the meantime, a significant decrease in these traits was recorded in the groups treated with capsaicin levels, indicating a good ameliorating effect with the used capsaicin.

As shown in Table 6, the activities of serum AST and ALT, as an indication of liver function, didn't significantly differ among all treatments due to dietary capsaicin inclusion indicated that it had no deleterious effect on liver cells. This result was supported by the finding of the (Saha and Das, 2003) who reported that, capsaicin have high level of antioxidant, this have modulating role on physiological function and biotransformation reaction involved in detoxification process there by providing protection from cytotoxic, genotoxic and metabolic effect of environment toxicant so inclusion of capsaicin caused stabilized cell membrane and protect the liver deleterious agent and free radicals mediated toxic damages to the liver cells which is desirable (Aderemi, et al., 2013). At the same time, El Husseiny et al. (2002) who found that, the addition of hot red pepper at level of 1, 1.5 and $2 \%$ in broiler diet had no any significant cumulative toxicity at doses administrated.

\section{Thyroid Gland Activity and Insulin Hormone}

As shown in Table 7, thyroid hormones $\left(\mathrm{T}_{3}\right.$ and $\left.\mathrm{T}_{4}\right)$ as well as their calculated ratios were significantly increased in a linear manner due to capsaicin supplementation especially with highest dosage. In addition, it is noticeable the lack of statistical significance between control, the low (50ppm) and the mid (100ppm) level. The excitation of the peripheral nervous system caused by capsaicinoids may lead to an increase in thyroliberin (TRH) secretion as a result of the activation of $\alpha$-adrenergetic receptors in the paraventricular nucleus (PVN). This, in turn, leads to an increase in the synthesis and secretion of TSH responsible for stimulating the release of total T4 by the thyroid gland (Shirpour et al., 2003).

As it was apparent from our results that treatment of ducks with capsaicin afforded a significant increase in serum thyroid hormones, these hormones influence all major metabolic pathways. Their most obvious and well known action is an increase in basal energy expenditure obtained acting on protein, carbohydrates and lipid metabolism. Thyroid hormones affect synthesis, mobilization and degradation of 
lipids, although degradation is influenced more than synthesis (Pucci et al., 2000). They favor lipolysis in adipose tissue resulting in a decrease in plasma cholesterol content and they may have an indirect effect on lipogenesis (Eshkhatkhah et al., 2010).

Table (7). Thyroid hormone activities, Insulin hormone, lipid peroxidase and antioxidant enzymes levels Pekin ducks fed supplemental capsaicin

\begin{tabular}{lcccc}
\hline \multirow{2}{*}{ Item } & \multicolumn{4}{c}{ Capsaicin levels $(\mathrm{ppm})$} \\
\cline { 2 - 5 } & 0 & 50 & 100 & 150 \\
\hline T3 $(\mathrm{ng} / \mathrm{ml})$ & $2.95^{\mathrm{b}} \pm 0.13$ & $2.60^{\mathrm{b}} \pm 0.12$ & $2.92^{\mathrm{b}} \pm 0.14$ & $3.85^{\mathrm{a}} \pm 0.13$ \\
$\mathrm{~T} 4(\mathrm{ng} / \mathrm{ml})$ & $14.64^{\mathrm{b}} \pm 0.20$ & $14.76^{\mathrm{b}} \pm 1.21$ & $15.06^{\mathrm{b}} \pm 0.31$ & $16.80^{\mathrm{a}} \pm 0.25$ \\
T3/T4 & $0.21^{\mathrm{ab}} \pm 0.02$ & $0.17^{\mathrm{b}} \pm 0.01$ & $0.19^{\mathrm{a}} \pm 0.01$ & $0.23^{\mathrm{a}} \pm 0.01$ \\
Insulin (ng/ml) & $2.14^{\mathrm{c}} \pm 0.11$ & $2.03^{\mathrm{c}} \pm 0.19$ & $4.34^{\mathrm{b}} \pm 0.09$ & $4.79^{\mathrm{a}} \pm 0.18$ \\
MDA nmol/ml & $0.21^{\mathrm{a}} \pm 0.01$ & $0.19^{\mathrm{a}} \pm 0.001$ & $0.16^{\mathrm{b}} \pm 0.001$ & $0.13 \pm 0.003$ \\
SOD (U/ml) & $149.69^{\mathrm{b}} \pm 1.60$ & $150.43^{\mathrm{b}} \pm 0.75$ & $154.88^{\mathrm{a}} \pm 0.47$ & $157.45^{\mathrm{a}} \pm 0.35$ \\
Catalase $(\mathrm{U} / \mathrm{ml})$ & $39.73^{\mathrm{b}} \pm 1.22$ & $40.56^{\mathrm{b}} \pm 1.02$ & $48.64^{\mathrm{a}} \pm 1.39$ & $49.35^{\mathrm{a}} \pm 1.54$ \\
\hline
\end{tabular}

$a, b$ and $c$ : Means within a row with different superscripts are significantly different at ( $p \leq 0.05)$.

As shown in Table (7) that dietary addition of capsaicin significantly increased serum insulin, especially with the mid and high dosages. These results suggest that insulin sensitivity is increased after capsaicin treatment. Support for this thought is found by studies of Spiridonov and Vorob'eva (2002) who showed that capsaicin stimulation of rats decreased the hypoglycemic action of insulin. Also, Zhou et al. (1990), they found that neonatal treatment with capsaicin decreased the hypoglycemic effect of insulin. Capsaicin protected $\beta$-cell mass by increasing proliferation and decreasing apoptosis (Kwon et al., 2013). The levels of plasma glucose, cholesterol, and triglycerides were also lower in the capsaicin-treated mice (Lee et al., 2013). On the other hand, Akiba et al (2004) has reported that the capsaicin receptor (TRPV1) is expressed on the beta cells of the pancreas and capsaicin could induce insulin secretion from the pancreas. It has been suggested that the effect of capsaicin on insulin secretion is due to more calcium influx into the cells. Beside the effect on insulin secretion, capsaicin may decrease plasma glucose by other mechanisms since capsaicin could inhibit glucose absorption from the intestine in canines and rodents (Monsereenusorn And Glinsukon, 1980).

\section{Lipid Peroxidation}

Heat stress increased lipid peroxidation as a consequence of increased free radical generation. The rise of lipid peroxidation resulted in increased MDA level in blood and tissues (Ates et al., 2006). In this way, the oxidative injury induced by high ambient temperatures (Mujahid et al., 2006) could be reduced by the action of some antioxidants like capsaicin aimed to alleviate the negative effects of heat.

As presented in Table 7, a highly significant reduction was obtained in the serum level of (MDA), which is the primary stable by-product of lipid peroxidation, in pekin ducks whose diets were containing various capsaicin levels in particular, the mid and high levels comparable to pekin ducks fed the control diet. Interestingly, capsaicin has the ability of free radical scavenger acting to reduce lipids available for peroxidation by transferring fatty acids into the mitochondria for the production of adenosine triphosphate (ATP) through -oxidation process (Tominaga et al., 2001). Furthermore, it is well known that, circulating free iron is able to catalyze ROS leading to lipid membrane degradation. Capsaicin has iron-chelating properties, which may prevent the generation of ROS by binding with free iron (Dairam et al., 2008).

Data presented in Table 7, that dietary addition of capsaicin significantly increased serum SOD, and CAT activities especially with the mid and high dosages. Whereas, ducks whose diet was contained the low capsaicin level had slightly higher serum SOD, and CAT activities when compared with the unsupplemented control ones. In the current study, capsaicin played antioxidant roles through enhancement of SOD, and CAT activities to scavenge the overproduction of ROS generated from heat stress. Consequently, by interfering with the production of these initial ROS, capsaicin was able to abrogate the MDA levels and thereby prevent the cell membrane breakdown by ROS.

Capsaicin project different tissue from oxidative damage because its ability antioxidant capacity (Kogure et al., 2002). This is in agreement with Henderson et al. (1999), who showed that the amide group present in capsaicin does not play a major role in its antioxidant activity under free radical oxidation conditions, that the antioxidant behavior for capsaicin was due primarily to the phenolic moiety in the molecule, and that the main product of capsaicin oxidation is its dimersdicapsaicin. Kogure et al. 
(Kogure et al., 2002) have found that the C-7 benzyl carbon, but not the phenolic OH group of capsaicin, is responsible for the scavenging site. Additionally, they found vanillin and 8-methyl-6-noneamide as products of capsaicin oxidative decomposition.

\section{CONCLUSION}

It is concluded that, dietary capsaicin supplementation with $100 \mathrm{ppm}$ up to $150 \mathrm{ppm}$ in Pekin ducks was sufficient to enhance the growth performance traits, thyroid activities and antioxidant system. Moreover, however, the present study pointed out that, capsaicin has the potentiality to modulate digestive enzyme activities. Further researches are needed to throw more clarification of mechanisms associated with these valuable effects.

\section{REFERENCES}

Aderemi, F., O. Alabi and O. Ayoola (2013). Evaluating pepper (Capsicum annuum) and Garlic (Allium sativum) on performance Egg trait and serum parameters of old layers. J. Of Biology, Agrci. and Healthcare PP: 3: No, 7.

Aebi, H. (1984). Catalase in Vitro. Method Enzym 105: 121-126.

Akiba, Y., S. Kato, K. Katsube, M. Nakamura, K. Takeuchi and H. Ishii (2004). Transient receptor potential vanilloid subfamily 1 expressed in pancreatic islet beta cells modulates insulin secretion in rats. Biochem Biophys Res Commun; 321: 219-25.

Al-Kassie, G.A.M., A.M.A. Mamdooh and J.A. Saba (2011). The effects of using hot red pepper as a diet supplement on some performance traits in broiler. Pakistan Journal of Nutrition.: 9, 842-845.

Al-Kassie, G.A.M., Y. Ghassan, B. Butris, J.A. Saba. and J. Ajeena (2012). The potency of feed supplemented mixture of hot red pepper and black pepper on the performance and some hematological blood traits in broiler diet. International Journal of Advanced Biological Research, 2(1): 53-57.

A.O.A.C. (1995). Official Methods of Analysis $15^{\text {th }}$ ed. Association of Official Analytical Chemists. Arlington, Virginia, USA.

Ates, B., M.I. Dogru, M. Gul, A. Erdogan, A.K. Dogru, I. Yilmaz, M. Yurekli and M. Esrefoglu (2006). Protective role of caffeic acid phenethyl ester in the liver of rats exposed to cold stress. Fundamental and Clinical Pharmacology, 20: 283-289.

Bajpai, V.K., A. Rahman, N.T. Dung, M.K. Huh and S.C. Kang (2008). In vitro inhibition of food spoilage and foodborne pathogenic bacteria by 3 essential oil and leaf extracts of Magnolia liliflora Desr. Journal of Food Science;73: M 14.

Barreto, M.S.R., J.F.M. Menten and A.M.C. Racanicci (2008). Plant extracts used as growth Ppromoters in broilers. Brazilian Journal of Poultry Science, v.10, p. 109-115.

Borges, S.A., A.V. Fischer, D.A. Silva and A. Maiorka (2007). Acid base balance in broilers. World's Poultry Science Journal, 63: 73-81.

Brugalli, I. (2003). Alimentação alternativa: a utilização de fitoterápicos ou nutracêuticos como moduladores da imunidade e desempenho animal. In: SIMPÓSIO SOBRE MANEJO E NUTRIÇÃO DE AVES E SUÍNOS, Campinas. Anais. Campinas: Colégio Brasileiro de Nutrição Animal, 2003. p.167-182.

Chevallier, A. (1996). The encyclopedia of medicina plants. Published by DK publishing Inc, USA.

Chiej, R. (1984). Encyclopaedia of Medicinal Plants. MacDonald. ISBN. 0-356-10541-5.

Choi, S.E., T.H. Kim, S.A. Yi, Y.C. Hwang, W.S. Hwang, S.J. Choe, S.J. Han, H.J. Kim, D.J. Kim, Y. Kang, and K.W. Lee.( 2011). Capsaicin attenuates palmitate-induced expression of macrophage inflammatory protein 1 and interleukin 8 by increasing palmitate oxidation and reducing c-Jun activation in THP-1 (human acute monocytic leukemia cell) cells. Nutrition Research, 31(6), 468478. 
Cordell, G.A. and O.E. Araujo (1993). Capsaicin: Identification, nomenclature and pharmacotherapy. Ann. Pharmacother. 27, 330-336.

Daghir N.J. (2009). Nutritional strategies to reduce heat stress in broilers and broiler breeders. Lohmann. Inf. 44:6-15.

Daghir, N.J. (1995). Poultry Production in Hot Climates. CABI, Wallingford, UK. Inf. 41:10-20.

Dairam A., R. Fogel, S. Daya and J.L. Limson (2008). Antioxidant and iron-binding properties of curcumin, capsaicin, and S-allylcysteine reduce oxidative stress in rat brain homogenate. Journal of Agricultural and Food Chemistry 56(9): 3350-3356.

Duncan, D.B. (1955). Multiple range and multiple F tests. Biometrics 1:1-42.

El Husseiny, O., S.M. Shalash and H.M. Azouz, (2002). Response of broiler performance to diet containing hot pepper and / or fenugreek at different metabolizable energy level. Egypt. Poult. Sci. (11): 387-406.

El Tazi, S.M.A. (2014). Response of broiler chicks to diet containing Capsaicin as natural feed additive. J. of Sci. and Tech., Omdurman Islamic Uni.4 (5): 81-86.

Eshkhatkhah, B., M. Sadaghian, S. Eshkhatkhah, S. Pourabi and K. Najafian (2010). Relationship between the blood thyroid hormones and lipid profile in Moghani sheep, influence of age and sex. Comp. Clin. Path., 19: 15-20.

Garcia, V., P. Cotala-Gregori, F. Hernandez, M.D. Megias and J. Madrid (2007). Effect of formic acid and plant extracts on growth, nutrient digestibility, intestine mucosa morphology and meat yield of broilers. Journal of Applied Poultry Research. 16:558-563.

Geraert P.A., J.C.F. Padilha, S. Guillaumin (1996 a). Metabolic and endocrine changes induced by chronic heat exposure in broiler chickens: Growth performance, body composition and energy retention. Br. J. Nutr. 75:195-204.

Hellgren, S., G. Flemstrom and O. Nylander (2000). Nitric oxide prevents rat duodenal contractions induced by potentially noxious agents. Acta Physiologica Scandinavica 169 (3):237-247.

Henderson, D.E., A.M. Slickman and S.K. Henderson (1999). Quantitative HPLC determination of the antioxidant activity of capsaicin on the formation of lipid hydroperoxides of linoleic acid: a comparative study against BHT and melatonin. J. Agric. Food Chem., 47, 2563-2570.

Henning, S.M., Y. Zhang, N.P. Seeram, R.P. Lee, P. Wang, S. Bowerman and D. Heber (2011). Antioxidant capacity and phytochemical content of herbs and spices in dry, fresh and blended herb paste form. International Journal of Food Sciences and Nutrition, 62(3), 219-25.

Holzer, P. and W. Sametz (1986). Gastric mucosal protection against ulcerogenic factors in the rat mediated by capsaicin-sensitive afferent neurons", Gastroenterology, 91:975-81.

Jamroz, D., T. Wertelecki, M. Houszka, and C. Kamel (2006). Influence of diet type on the inclusion of plant origin active substances on morphological and histochemical characteristics of the stomach and jejunum walls in chicken. J. Anim. Physiol. Anim. Nutr. (Berl.) 90:255-268.

Jamroz, D., T.J. Wertlecki, J. Orda, A. Wiliczkiewicz, and J. Skorupińska (2003). Influence of phtogenic extracts on gut microbial status in chickens. In: Proc. $14^{\text {th }}$ European Symp. on Poultry Nutrition, August, Lillehammer, Norway. pp. 176.

Kang, J.H, T. Goto, I.S. Han, T. Kawada, Y.M. Kim and R. Yu (2010). Dietary capsaicin reduces obesityinduced insulin resistance and hepatic steatosis in obese mice fed a high-fat diet. Obesity (Silver Spring). Apr, 18(4):780-7.

Kang, J.H, Y.M. Kim, I.S. Han T. Kawada and R. Yu (2007). Capsaicin, a spicy component of hot peppers, modulates adipokine gene expression and protein release from obese-mouse adipose tissues and isolated adipocytes, and suppresses the inflammatory responses of adipose tissue macrophages. FEBS. Lett., 581, 4389-4396.

Kawada, T., S. Sakabe, T. Watanabe, M. Yamamoto and K. Iwai (1988). Some pungent principles of spices cause the adrenal medulla to secrete catecholamine in anesthesized rats. Proc. Soc. Exp. Biol. Med. 188, 229-233.

Kawada, T., T. Watanabe, T. Nakaishi, T. Tanaka and K. Iwai (1986). Capsaicin-induced beta adrenergic action on energy metabolism in rats: influence of capsaicin on oxygen consumption, the respiratory 
quotient and substrate utilization. Proceeding of the Society for Experimental Biology and Medicine $183,250-256$.

Kogure, K., S. Goto, M. Nishimura, M. Yasumoto, K. Abe, C. Ohiwa, H. Sassa , T. Kusumi and H. Terada (2002). Mechanism of potent antiperoxidative effect of capsaicin. Biochimica et Biophysica Acta, 1573(1), 84-92.

Kwon, D.Y., Y.S. Kim, Y.R. Shi, M.R. Cha, G.H. Yon, H.J. Yang, J.K. Min, S. Kang and S. Park (2013). Capsiate improves glucose metabolism by improving insulin sensitivity better than capsaicin in diabetic rats. J. Nutr. Biochem., 24, 1078-1085.

Lee, C.Y.J., M. Kim, S.W. Yoon and C. H. Lee (2003). Short-term control of capsaicin on blood and oxidative stress of rats in vivo. Phytother. Res. 17:454-458.

Lee, G.R., M.K. Shin, D.J. Yoon, A.R. Kim, R. Yu, N.H. Park and I.S. Han ( 2013). Topical application of capsaicin reduces visceral adipose fat by affecting adipokine levels in high-fat diet-induced obese mice. Obesity, 21, 115-122.

Lee, K.W., H. Everts and A.C. Beynen (2004). Essential oils in broilers nutrition. International Journal of Poultry Science, v.3, p.738-752.

McElroy, A.P., J.G. Manning, L.A. Jaeger, M. Taub, J.D. Williams and B.M. Hargis (1994). Effect of prolonged administration of dietary capsaicin on broiler growth and Salmonella enteritidis susceptibility. Avian Dis., 38:329-333.

Monsereenusorn, Y. and T. Glinsukon (1980). Effect of capsaicin on plasma glucose level and intestinal glucose absorption in vivo. Mahidol Univ J Pharm Sci; 7: 9-12.

Mujahid, A., K. Sato, Y. Akiba, M. Toyomizu (2006). Acute heat stress stimulates mitochondrial superoxide production in broiler skeletal muscle, possibly via downregulation of uncoupling protein content. Poult. Sci. 85:1259-1265.

Nishikimi, M., N.A. Roa and K. Yagi (1972). The occurrence of superoxide anion in the reaction of reduced phenazine methosulfate and molecular oxygen. Biochem Biophys Res Commun 46: 849854.

Nitsan, Z., E.A. Dunnington and P.B. Siegel (1991). Organ growth and digestive enzyme levels to fifteen days of age in lines of chickens differing in body weight. Poult. Sci., 70: 2040-2048.

Nomoto, S., M. Shibata, M. Iriki and W. Riedel (2004). Role of afferent pathways of heat and cold in body temperature regulation. International Journal of Biometeorology 49, 67-85.

NRC (National Research Council) (1994). Nutrient requirements of poultry. ( $9^{\text {th }}$ Rev. ed) National Academy Press, Washington, DC. U.S.A.

Ohkawa, H., N. Ohishi and K. Yagi (1979). Assay for lipid peroxides in animal tissues by thiobarbituric acid reaction. Anal. Biochem. 95: 351-385.

Ononiwu, G., R.L. Puntelb and J.B.T. Rochab (2002). Hot pepper (Capsicum annuum, Tepin and Capsicum chinese, Habanero) prevents Fe2+-induced lipid peroxidation in brain - in vitro. Food Chemistry. 102: (1).178-185.

Platel, K. and K. Srinivasan (2004). Digestive stimulant action of spices: A myth or reality? Indian J Med Res 119, May, pp 167-179.

Platel, K. and K. Srinivasan (2000). Influence of dietary spices and their active principles on pancreatic digestive enzymes in albinorats. Nahrung, v.44, p.41-46.

Pruthi, J.S. (2003). Chemistry and quality control of capsicum and capsicum products. In Capsicum and the genus Capsicum. Amit Krishna De. (eds). CRC Press, Taylor and Francois, UK. Pp 25-71.

Pucci, E., L. Chiovato and A. Pinchera (2000). Thyroid and lipid metabolism. Inter. J. Obes. Rel. Met. Dis., 24(2): 109-112.

Raben, A., J.J. Holst, N.J. Christensen and A. Astrup (1996). Determinants of postprandial appetite sensations: macronutrient intake and glucose metabolism. Int. J. Obes., 20: 161-169.

Rashidi, A.A., Y. Gofrani lvari, A. khatibjoo and R. Vakili (2010). Effects of dietary fat, vitamin E and zinc on immune response and blood parameters of broiler reared under heat stress. Research Journal of Poultry Sciences, 3: 32-38. 
Rawel, H.M., D. Czajka, S. Rohn and J. Kroll (2002). Interactions of different phenolic acid and flavonoids with soy proteins. Int. J. Biol. Macromol. 30:137-150.

Saha, P. And S. Das (2003). Regulation of hazardous exposure by protective exposure modulation of phase II detoxification and lipid peroxidation by Camellia sinensis and swertia chirata Teratog Carcinog Mutagen Suppl. 1: 313-322.

SAS (2001). SAS User's guide: Statistics, Version 9th Ed. SAS Institute Inc., Cary N.C., USA.

Shan, B., Y.Z. Cai, J.D. Brooks and H. Corke (2007). The in vitro antibacterial activity of dietary spice and medicinal herb extracts. International Journal of Food Microbiology, 112-117.

Shirpour, A., S. Khameneh, N. Zarghami, and M. Eskandari (2003). The Influence of Hypothermia on Thyroid Function in Rats. Int. J. Endocrinol. Metab., 1, 27- 32.

Spiridonov VK and N.F. Vorob'eva (2000). The effects of stimulation and lesioning of afferent nerves on blood glucose and free fatty acid contents in rats in conditions of changing glycemia. Neurosci Behav Physiol 30: 207-211,.

Srinivasan, K. and K. Sambaiah (1991). The effect of spices on cholesterol 7- alfa-hydroxylase activity and on serum and hepatic cholesterol levels in the rat. Int. J. Vitam. Nutr. Res. 61: 364-369.

Szoscanyi, J. and L. Bartho (2001). Capsaicin-sensitive afferents and their role in gastroprotection: an update. Journal of Physiology 95, 181-188.

Tellez, G.I., C.E. Jaeger, D.E. Dean, D. Corrier and J.R. Deloach (1993). Effect of prolonged administration of dietary capsacin on Salmonella enteritis infection in leghorn chicks. Avian Dis., 37:143-148.

Tominaga M., M. Wada and M. Masu (2001). Potentiation of capsaicin receptor activity by metabotropic ATP receptors as a possible mechanism for ATP-evoked pain and hyperalgesia. Proc Natl Acad Sci USA 98: 6951-6956.

Vicente, J.L., C. Lopez, E. Avila, B.M. Hargis and G.I. Tellez (2007). Effects of dietary natural capsaicin on experimental salmonella enteritis infection and yolk pigmentation in laying hens. International Journal of Poult. Sci. 6, 393-396.

Yu, R., J.W. Park, T. Kurata and K.L. Erickson (1998). Modulation of select immune response by dietary capsaicin. International Journal for Vitamin and Nutrition Research 68, 114-119.

Zhou, X.F., K.H. Jhamandas and B.G. Livett (1990). Capsaicin-sensitive nerves are required for glucostasis but not for catecholamine output during hypoglycemia in rats. Am J Physiol 258: E212219 ,

Zhukova, E.M. and O.P. Makarova (2002). Effect of capsaicin on dynamics of neutrophil functional activity in wistar rat venous blood. Bulletin of Experimental Biology and Medicine 134, 233-235. 
تاثير اضافة الكابسيسين فى العليقة على الاداء الإنتاجي والفسيولوجي للبط البيكينى خلال فصل الصيف

\author{
وائل على حسن 1 ـ ايمن محم حسن أحمد² ـ هدى الجابرى3 \\ 1 قسم بحوث تربية الأرانب والرومى والطيور المائية، معهل بحوث الإنتاج الحيوانى، مركز البحوث الزراعية، مصر.

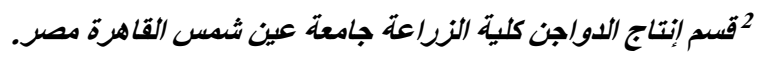



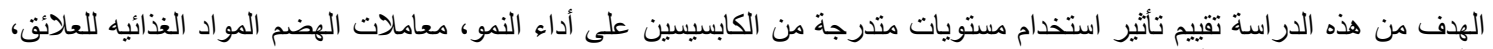

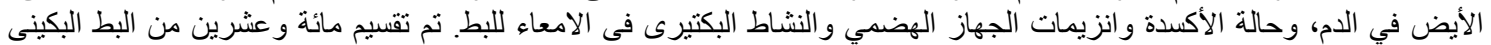

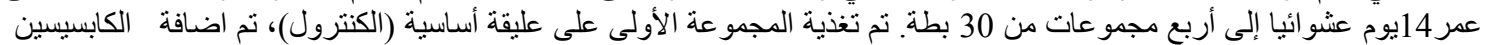

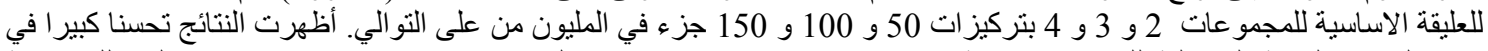
وزن الجسم والكفائة التحويلية للغذاء ، وخاصة مع ارتفاع مستوى (ppm 150) يليها مستوى(

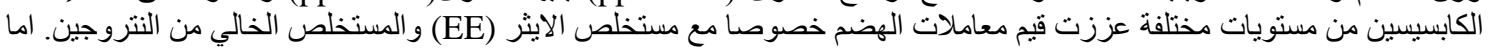

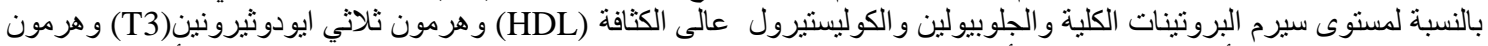



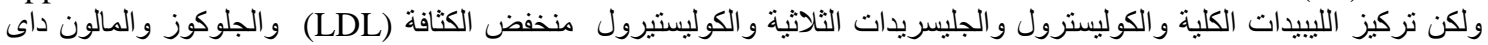

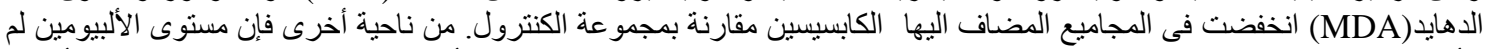

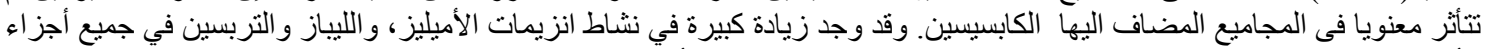

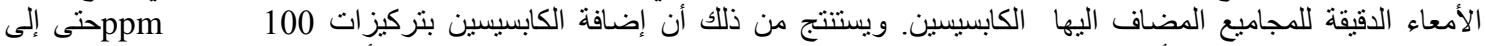

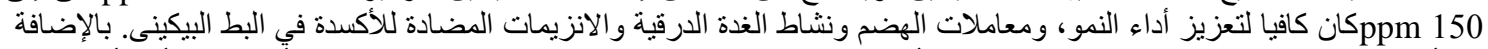

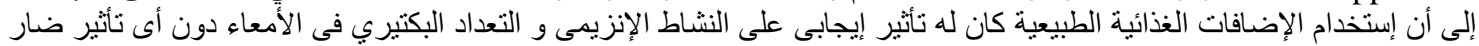

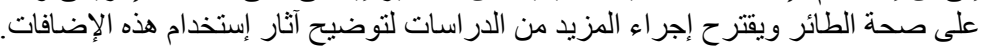

